\title{
Impact of global climate change and fire on the occurrence and function of understorey legumes in forest ecosystems
}

\section{Frédérique Reverchon • Zhihong Xu・ Timothy J. Blumfield • Chengrong Chen • Kadum M. Abdullah}

\author{
F. Reverchon $(\bowtie) \cdot$ Z. H. Xu $(\bowtie) \cdot$ T. J. Blumfield • C. R. Chen • K. M. Abdullah \\ Environmental Futures Centre and School of Biomolecular and Physical Sciences, Griffith University, Kessels Road 170, \\ Nathan, QLD 4111, Australia \\ e-mail: $\underline{\text { f.reverchon@ griffith.edu.au; zhihong.xu@ griffith.edu.au }}$
}

\section{(凹) Corresponding authors:}

Frédérique Reverchon and Zhihong $\mathrm{Xu}$

Phone: (07) 37353822

Fax: (07) 37354209

e-mail: $\underline{\text { f.reverchon@griffith.edu.au; zhihong.xu@griffith.edu.au }}$

\begin{abstract}
The objective of this review was to provide a better understanding of how global climate change and fire influence the occurrence of understorey legumes and thereby biological nitrogen $(\mathrm{N})$ fixation rates in forest ecosystems. Legumes are interesting models since they represent an interface between the soil-, plant-, and microbial-compartments, and are directly linked to nutrient cycles through their ability to fix N. As such, they are likely to be affected by environmental changes. Biological $\mathrm{N}$ fixation has been shown to increase under enriched $\mathrm{CO}_{2}$ conditions, but is constrained by the availability of phosphorus and water. Climate change can also influence the species composition of legumes and their symbionts through warming, altered rainfall patterns or changes in soil physicochemistry, which could modify the effectiveness of the symbiosis. Additionally, global climate change may increase the occurrence and intensity of forest wildfires thereby further influencing the distribution of legumes. The establishment of leguminous species is generally favored by fire, as is $\mathrm{N}_{2}$ fixation. This fixed $\mathrm{N}$ could therefore replenish the $\mathrm{N}$ lost through volatilization during the fire. However, fire may also generate shifts in the associated microbial community which could affect the outcome of the symbiosis. Understorey legumes, because they represent key ecological processes, respond rapidly to environmental changes and are closely associated with soil microbes, could be used to monitor the responses of forest ecosystems to global warming or fire. This would be helpful to accurately model ecosystem $\mathrm{N}$ budgets, and since $\mathrm{N}$ is often a limiting factor to plant growth and a major constraint on $\mathrm{C}$ storage in ecosystems, would allow us to assess more precisely the potential of these forests for $\mathrm{C}$ sequestration.
\end{abstract}


Keywords Global climate change $\bullet$ Nitrogen fixation $\bullet$ Fire $\bullet$ Rhizobia $\bullet$ Understorey legumes

\section{Introduction}

Legumes are broadly distributed across the globe and are important components of the understorey of forest ecosystems. They are especially present in Australian eucalypt-dominated forests, which represent $79 \%$ of the native forest estate of the continent (National Forest Inventory 2007). Understorey legumes are critical for the ecosystem functioning of these forests since they can fix nitrogen $(\mathrm{N})$ through their association with $\mathrm{N}$-fixing bacteria, and are able to increase the quantity of $\mathrm{N}$ and phosphorus (P) cycled through litterfall (Guinto et al. 2000; Forrester et al. 2005). These symbiotic associations, combined with other competitive physiological traits such as their resistance to drought, permit them to colonize disturbed lands and to quickly re-establish after fires. This makes understorey legumes adequate species for ecological restoration in the tropics (Adams et al. 2010). Understorey legumes play a crucial role in the $\mathrm{N}$ balance of forest soils. However, relatively little information exists about the taxonomic and functional diversity of the interactions between native understorey legumes and their symbionts (Hoque et al. 2011).

Biological $\mathrm{N}_{2}$ fixation is the major natural process providing $\mathrm{N}$ inputs to the soil and as such, an important biogeochemical mechanism for forest productivity. It can occur through free-living or symbiotic microbial pathways (van Groenigen et al. 2006), and because it is one of the most energy-demanding biological processes on Earth, it closely depends on carbon (C) supply as an energy source. Furthermore, it requires 16 molecules of ATP per mole of $\mathrm{N}_{2}$ fixed which makes it strongly constrained by $\mathrm{P}$ at molecular scales (Vitousek et al. 2002). The $\mathrm{C}, \mathrm{N}$ and $\mathrm{P}$ biogeochemical cycles are essential to sustain life on Earth. Living organisms require these elements in exact proportions, especially because the cycles of $\mathrm{C}, \mathrm{N}$, and P are coupled from molecular to global scales (Gruber and Galloway 2008). This stoichiometric balance is fundamental for maintaining forest ecosystem diversity, functioning, and stability (Finzi et al. 2011). Environmental changes such as elevated atmospheric $\mathrm{CO}_{2}$ and temperature, atmospheric $\mathrm{N}$ deposition, land-use change or forest fires, have modified this fragile balance. How forest ecosystems are responding to these modifications is still unclear, and it is necessary to understand the underlying processes regulating these responses in order to be able to predict how $\mathrm{C}$ and nutrient cycles will be affected in the long term (Beedlow et al. 2004; Magnani et al. 2007; Chen and Xu 2010; Owens and Xu 2011).

Soil microbial communities, because they are mainly heterotrophic and are parts of the belowground processes, are likely to be affected as well by the stoichiometry changes in C, N and P due to environmental change (Chen and Xu 2010). Although a large amount of information has been published on the influence of global environmental changes on forest ecosystems (e.g. Sitch et al. 2008; Allen et al. 2010; Liu et al. 2011a), most of it deals with the aboveground ecosystem components (Xu and Chen 2006; Liu et al. 2011b). There is increasing evidence that above- and below-ground processes are intimately linked (Heimann and Reichstein 2008) and it is therefore critical to adopt a change of framework in order to unravel the impacts of environmental alterations on plant-soil-microbe interactions and ultimately on ecosystem functioning. Understorey legumes and their associated microbiota represent a perfect example of the interrelations existing between the soil-, plant-, and microbial-compartments of forest ecosystems, and are directly linked to nutrient cycles through biological $\mathrm{N}_{2}$ fixation. The objective of this review was to provide a better understanding of how environmental stressors, such as global climate change or fire, influence legume distribution and functioning in forest ecosystems. We also 
comment on the potential role of understorey legumes to mitigate the impacts of such environmental changes and to monitor the responses of eucalypt-dominated forests to environmental changes.

\section{The impact of global climate change on understorey legumes}

\subsection{Global climate change affects forest growth through photosynthesis and water use efficiency}

Over the last century, fossil fuel burning and land-use change have caused atmospheric $\mathrm{CO}_{2}$ concentration to increase globally by nearly $30 \%$ and temperature by approximately $0.6^{\circ} \mathrm{C}$, and these increases are projected to continue even more rapidly (IPCC 2007). The impacts of global climate change on long-term forest growth and C sequestration have raised concern worldwide (Oren et al. 2001; Reich et al. 2006; Heimann and Reichstein 2008; Chen and Xu 2010). First, trees should be able to adjust their physiological responses over time to gradually changing environmental conditions (Dawson et al. 2011) but in the long-term, gradual and step increases in atmospheric $\mathrm{CO}_{2}$ concentration could generate negative effects on plant photosynthesis (Sun et al. 2010). Because increased $\mathrm{CO}_{2}$ did not occur in isolation but was accompanied by elevated $\mathrm{N}$ deposition and altered cycles of elements due to anthropogenic activities, the outcomes of global climate change are even more difficult to predict (Xu et al. 2009; Owens and $\mathrm{Xu}$ 2011). Most studies conclude that elevated $\mathrm{CO}_{2}$ concentration should increase photosynthesis by stimulating the carboxylation rate of Rubisco and reducing photorespiration (Schimel 1995; Atkin et al. 1999), provided that available $\mathrm{N}$ and water are present in sufficient amounts (Liu et al. 2010, 2011a). As shown in Table 1, greater stimulation of photosynthesis and growth of legumes and actinorhizal plants, compared to non- $\mathrm{N}_{2}$-fixers, is expected under elevated $\mathrm{CO}_{2}$ concentration (Soussana and Hartwig 1996; Zanetti et al. 1996; Rogers et al. 2006; Tobita et al. 2010). Even when these physiological responses vary among $\mathrm{N}_{2}$-fixing species and genotypes (Reich et al. 2001; West et al. 2005), they confer them with an advantage to cope with global climate change. This is due to the ability of $\mathrm{N}_{2}$-fixers to maximize the benefits of elevated $\mathrm{CO}_{2}$ concentration by counteracting $\mathrm{N}$ limitation and decreasing the negative impact of drought on biological N fixation (Rogers et al. 2009).

Water stress will thus become increasingly critical for the functioning of forest ecosystems. Water is closely coupled with the $\mathrm{C}$ cycle through photosynthesis and indirectly influences nutrient availability through soil moisture. The hydrological cycle is altered by global climate change through the increase in global temperature and its consequent effects on rainfall patterns. Seasonal variation in precipitation may deeply affect ecosystem productivity as any change in the frequency or timing of rainfall may determine whether water will be taken up by plants or lost by evaporation or run-off (Heimann and Reichstein 2008). Plant responses to water shortage, such as water use efficiency (WUE) and resilience to drier environmental conditions, will be crucial for maintaining forest productivity under elevated $\mathrm{CO}_{2}$ concentrations. It has been predicted that the increase in plant photosynthesis and the reduction in stomatal conductance originating from rising $\mathrm{CO}_{2}$ should result in lower transpiration rates and consequently in higher plant water use efficiency (Nelson et al. 2004; Peñuelas et al. 2009). Species with higher WUE may therefore possess an adaptive advantage to stand the expected drier conditions provoked by climate change in many parts of the world. Recently, Gebrekirstos et al. (2011) used stable C isotope techniques to investigate the ability of different Acacia species to withstand drought, and reported that species with lower water potentials and hence higher WUE demonstrated a conservative water use strategy under water stress conditions. However, this higher plant WUE might be offset by decreasing plant photosynthesis after the tipping point in forest productivity is passed (Xu et al. 2009; Laurance et al. 2011). 


\subsection{Influence of global climate change on $\mathbf{N}$ fixation and $\mathbf{N}_{\mathbf{2}}$-fixing microorganisms}

Legumes and their associated soil microorganisms are sensitive to environmental changes, especially to increases in atmospheric $\mathrm{CO}_{2}$ concentrations (Jablonski et al. 2002). Symbiotic $\mathrm{N}$-fixing bacteria, such as rhizobia or the actinomycete Frankia, are known to benefit from plant growth under elevated $\mathrm{CO}_{2}$ conditions (Rogers et al. 2009). The availability of $\mathrm{N}$ supplies is particularly relevant in order to delay the negative effects of elevated $\mathrm{CO}_{2}$ concentrations on forest productivity. Enhanced biological $\mathrm{N}$ fixation has been therefore suggested as a means to provide the $\mathrm{N}$ necessary to support $\mathrm{C}$ accumulation under rising atmospheric $\mathrm{CO}_{2}$ concentration (Finzi et al. 2007), which would make biological $\mathrm{N}$ fixation a key process for mitigating environmental change. Increases in the size of symbiotic rhizobial populations (Schortemeyer et al. 2002), in the size and number of root nodules (Serraj et al. 1998; Tobita et al. 2010) or in nitrogenase activity (Soussana and Hartwig 1996) are common effects of atmospheric $\mathrm{CO}_{2}$ enrichment, provided $\mathrm{P}$ is supplied in sufficient amounts. Some studies showed that $\mathrm{N}$ fixing plants are also able to increase the availability of $\mathrm{P}$ in soil through their phosphatase activity (Houlton et al. 2008), though it might be of direct benefit for the legumes that produced that enzyme activity. This capacity to remobilize P implies that woody legumes are able to succeed in establishing where other plants may fail due to poor supplies of water and $\mathrm{P}$.

The relative contribution of symbiotically-fixed $\mathrm{N}$ has been shown to increase under elevated $\mathrm{CO}_{2}$ concentrations since the increasing plant demand for $\mathrm{N}$, as a result of an enhanced growth, cannot be fulfilled by available mineral $\mathrm{N}$ (Lüscher et al. 2000). However, other studies reported that the presence of legumes does not prevent a gradual decrease in biomass response under elevated $\mathrm{CO}_{2}$ and moderated the role of $\mathrm{N}_{2}$ fixation in $\mathrm{C}$ storage (Reich et al. 2006). The enhancement of biological $\mathrm{N}$ fixation under such conditions may be species specific (West et al. 2005) and is constrained by the availability of other nutrients, such as P, potassium or molybdenum (Hungate et al. 2004; van Groenigen et al. 2006). The P-limitation of this increase in $\mathrm{N}_{2}$ fixation has been demonstrated for actinorhizal plants as well (Tobita et al. 2010). Since biological $\mathrm{N}$ fixation is an energy-demanding process which requires P (Forrester et al. 2005), it is consequently closely linked to other nutrient cycles and is therefore likely to be influenced by any change in environmental conditions.

If the impact of $\mathrm{CO}_{2}$ enrichment on $\mathrm{N}_{2}$-fixing relationships is generally well documented, the effects of other environmental changes, such as warming and water shortage, are less studied. The $\mathrm{N}_{2}$-fixing plants are indirectly influenced by warming since biological $\mathrm{N}$ fixation is strongly temperature dependent, with a maximum at around $25^{\circ} \mathrm{C}$ (Houlton et al. 2008; Adams et al. 2010). The $\mathrm{N}_{2}$ fixation is enzymatic and energy-demanding, hence any temperature constraint could enhance its C cost (Vitousek and Field 1999). The magnitude of the effect of an increase in temperature may depend on the legume species and on their particular distribution. In his work about projected impacts of climate change in Australia, Hughes (2003) concluded that Acacia species may be relatively robust to modest warming, since only one species would be threatened by its bioclimate disappearance with a $0.5^{\circ} \mathrm{C}$ increase in global temperature. However, the bioclimates of $59 \%$ of Acacia species would be expected to disappear with a $1^{\circ} \mathrm{C}$ increase and would totally disappear with a $2^{\circ} \mathrm{C}$ warming.

Lack of rain and rising temperatures also increase the soil salinity, creating an osmotic stress which affects both the plant and its symbionts. Coping mechanisms include the accumulation in the bacterial cell of potassium or other low molecular weight organic solutes, which protect the cells against hyperosmotic stress or desiccation (Essendoubi et al. 2007). These solutes have been found in various rhizobial strains growing in drought-prone ecosystems (Zahran 2001). 
Because rhizobial strains vary in salt tolerance, shifts in symbiont community composition may have drastic effects for the ecological success of their hosts, hence mediating host adaptation to stressed environments (Thrall et al. 2009). Changes in environmental conditions due to climate change may also modify the plant dependence on the symbiosis, especially when the associated microorganisms themselves are sensitive to environmental change (Thrall et al. 2008). In harsher conditions, successful plant establishment may depend on the microbial adaptation to the environmental stressor, as in the case of salttolerant rhizobial strains. On the contrary, the cost of maintaining the symbiosis under environmental stress might become too high for the plant to sustain.

The increasing levels of $\mathrm{CO}_{2}$ in the atmosphere are unlikely to directly affect soil organisms, since the concentration of $\mathrm{CO}_{2}$ already present in pore spaces of most soils would probably buffer any atmospheric increase (Pritchard 2011). However, plant physiology is directly affected by $\mathrm{CO}_{2}$ enrichment, which may therefore impact the plant belowground symbionts (Xu et al. 2009; Owens and $\mathrm{Xu}$ 2011). Trees growing in $\mathrm{CO}_{2}$-enriched atmospheres have been reported to present significant increases in root production (e.g. Norby et al. 2004), which represents an increase in the resources made available to the soil microbial communities. The release of more labile organic compounds into the rhizosphere is expected to change the size and the activity of soil microbiota, increasing mycorrhizal or $\mathrm{N}_{2}$-fixation associations, resulting in higher rhizosphere microbial activities per unit of root growth (Pritchard 2011). Increased activity may in turn enhance organic matter decomposition and increase $\mathrm{N}$ mineralization rates and $\mathrm{N}$ uptake by plants, as well as the loss of soil C (Fig. 1). This exchange of tree $\mathrm{C}$ for soil $\mathrm{N}$, with the amount of $\mathrm{C}$ allocated to the soil determined by soil $\mathrm{N}$ availability, appears to maintain high forest productivity under elevated $\mathrm{CO}_{2}$ (Drake et al. 2011). However, the greater immobilization of soil nutrients, in particular of soil $\mathrm{N}$, due to the increasing organic $\mathrm{C}$ input to the soil, could soon lead to progressive nutrient limitations (Beedlow et al. 2004; Chen and Xu 2010). This would challenge the plant's capacity to respond to elevated atmospheric $\mathrm{CO}_{2}$, thereby resulting in a decrease in plant productivity over time, as suggested by Drigo et al. (2008).

Different plant species may possess a different potential to adapt to warming and water stress. An increase in temperature due to climate change may thus change plant species composition and consequently alter their associated microbiota. Host community structure plays a fundamental role in shaping symbiotic interactions and effectiveness (Thrall et al. 2011) and therefore ecosystem productivity and diversity. Overall, the effect of global climate change on biological $\mathrm{N}$ fixation may probably be twofold since adverse conditions can alter both legumes and their symbiotic bacteria. Increasing atmospheric $\mathrm{CO}_{2}$ concentrations are unlikely to stimulate all groups of soil organisms equally, and changes in soil community composition will probably occur. Studies about the influence of global climate change on soil microbial communities suggest that energy flows through fungal pathways may be enhanced relative to bacterial pathways by both warming and atmospheric $\mathrm{CO}_{2}$ enrichment (Abera et al. 2011; Pritchard 2011). Fungi have lower $\mathrm{N}$ requirements than bacteria and may therefore be favored by higher litter $\mathrm{C}: \mathrm{N}$ ratios and by the increased exudation of organic $\mathrm{C}$ compounds into the rhizosphere, although recent findings do not validate this hypothesis (Blankinship et al. 2011). Drake et al. (2011) demonstrated the importance of fungal community composition in ecosystems affected by warming and suggested that fungi, by conditioning soil nutrient availability, may mediate the effects of elevated $\mathrm{CO}_{2}$ on forest productivity. In any case, a shift from bacterial- to fungal-dominated soil microbial communities would have important implications for $\mathrm{N}_{2}$-fixing plants which form symbiotic associations with both and consequently for the ecosystem response to increasing $\mathrm{CO}_{2}$ concentrations (Langley and Megonigal 2010). 


\section{The impact of fire on understorey legumes}

\subsection{Wildfires affect the establishment of understorey legumes}

Forest fires represent an element of global climate change which enhances greenhouse gas concentrations through the release of $\mathrm{C}$ and $\mathrm{N}$ as gases and particulates into the atmosphere and might accelerate negative responses of forest ecosystems to climate change (Allen et al. 2010). Alternatively, global climate change may increase the occurrence and intensity of forest wildfires by changing rainfall, temperature and air humidity patterns, thus enhancing drought conditions (Neary et al. 1999). Feedbacks between physiological stress driven by climate change and other forest disturbance processes such as fire are poorly understood (Allen et al. 2010), especially because they intervene at different scales: whereas climate change acts at a global scale by increasing atmospheric $\mathrm{CO}_{2}$ concentrations and temperatures, fire has a more local influence on forest ecosystems (Xu et al. 2009; Owens and Xu 2011).

Wildfires are frequent in ecosystems ranging from tropical semiarid savannas to American temperate forests, where $\mathrm{N}$ is often a common limiting factor for tree growth (Hainds et al. 1999; Caldwell et al. 2002). Legumes are ubiquitous in firedependent ecosystems since they often need fire to germinate. As part of the understorey, they are directly affected by wildfires. Various studies reported that the establishment of $\mathrm{N}_{2}$-fixing vegetation was promoted by frequent fires which decreased the competitive exclusion of legumes once established (Hendricks et al. 1999; Newland and DeLuca 2000). This higher density of legumes and actinorhizal plants following fire thereby increases biological $\mathrm{N}$ fixation rates, which in turn enhance the rates of soil $\mathrm{N}$ cycling through the input of higher quality litter to the soil (Hart et al. 2005). Other studies, however, showed that this increase in legume abundance was season-dependent, and that unlike winter fire, summer fire seemed to constrain $\mathrm{N}_{2}$-fixing plants, probably due to its effect on flowering and seed production (Hainds et al. 1999). Moreover, the dominance of legume species can in some cases cause problems for trees to re-establish, thereby delaying the replenishment of C pools (Johnson et al. 2005).

Wildfires also affect legume distribution through indirect pathways, by altering biogeochemical cycles (Fig. 2). N volatilization results in lower pools of plant available and total $\mathrm{N}$, and some of the vegetation types which have been found to dominate post-fire ecosystems produce slowly-decomposing recalcitrant litter resulting in immobilization of $\mathrm{N}$ (Reich et al. 2001). The reduction in plant biomass following forest fires may induce changes in $\mathrm{C}$ dynamics since woody cover has been shown to promote the sequestration of both $\mathrm{C}$ and $\mathrm{N}$ (Coetsee et al. 2010). Furthermore, by modifying soil moisture conditions and elevating soil temperature, fire may generate some shifts in nutrient availability, as well in soil chemical and physical properties. The resulting loss of organic matter, the alteration of nutrient availability by leaching of soluble ions, and the modification of soil moisture levels will induce changes in the occurrence of leguminous species, which are known to vary in their tolerance to drought (Sprent 1995). Belowground processes will be affected as well (Guinto et al. 1999b), and losses of $\mathrm{C}$ due to the burning may be accelerated by increases in microbial activity due to elevated soil temperatures (Treseder et al. 2004). On the other hand, they may be counterbalanced through the deposition of charcoal in the soil, which contributes significantly to the soil C pool, especially in fire-maintained forest ecosystems (DeLuca and Aplet 2008). There may be a variety of other ecological and management factors which affect legume distribution, and a better understanding of the spatial and temporal responses of legume species to different burning regimes and resources is required. Furthermore, changes in the distribution and occurrence of $\mathrm{N}_{2}$-fixing plants following fire are probably modifying as well the abundances 
of their symbionts, ultimately altering the community composition and activities of other soil microorganisms (Table 1).

\subsection{Wildfire impact on biological $\mathbf{N}$ fixation and $\mathrm{N}_{2}$-fixing microorganisms}

The impact of fire on biological $\mathrm{N}$ fixation has received much attention, especially because fire-adapted legumes may play a relevant role in replacing $\mathrm{N}$ lost by volatilization (Hendricks and Boring 1999). On low-fertility sites, even small $\mathrm{N}_{2}$ fixation values can represent a long-term source to restore soil $\mathrm{N}$ levels following disturbance (Busse et al. 2007). $\mathrm{N}_{2}$-fixing plants may also favor the input into the forest soil of higher quality litter with lower C:N ratio (Newland and DeLuca 2000). Fires have been showed to increase Acacia nodulation in eucalypt-dominated forests (Guinto et al. 2000) and may promote the ability of legumes to fix $\mathrm{N}_{2}$ by making soil conditions more favorable. Low intensity fires reduce soil available $\mathrm{N}$ by $\mathrm{N}$ mineralization and enhance soil available P, both propitious to biological $\mathrm{N}$ fixation (Vitousek et al. 1999). However, $\mathrm{N}_{2}$ fixation is often constrained by water shortage. Increasing drought stress under frequent fire events is likely to contribute to a decrease in leaf area, thereby reducing the quantity of photosynthates necessary to maintain nodule biomass and $\mathrm{N}_{2}$ fixation rates (Hendricks and Boring 1999). Furthermore, frequent fires may not be as favorable to legumes, since the quantity of $\mathrm{N}$ fixed between fires would be smaller than the $\mathrm{N}$ lost during the fires. Newland and DeLuca (2000) concluded that a critical assessment of the temporal patterns of biological $\mathrm{N}$ fixation is necessary to develop reliable long term $\mathrm{N}$ budgets.

Direct fire impacts on rhizobial and actinorhizal communities may occur through heat-induced mortality. Furthermore, indirect effects are likely to arise due to the modification of the soil environment through heating, oxidation and new inputs to the soil system of charcoal, distillates metal oxides, and plant litter (Hart et al. 2005). Some groups of microbes are more sensitive to heating than others, which can result in shifts in the size, activity, and composition of the soil microbial community. Abera et al. (2011) showed that the microorganisms involved in soil $\mathrm{N}$ transformation processes have different sensitivity levels to water availability, which may modify community composition at the rhizosphere level. Bacteria are acknowledged to be more tolerant to heat than fungi, and since most legume species present symbiotic associations with both rhizobial bacteria and mycorrhizal fungi (Diédhiou et al. 2005; Adams et al. 2010), they would be directly affected by such changes in soil microbial community composition. Arbuscular mycorrhizal fungi have been shown to be more tolerant to heat than asymbiotic fungi (Hart et al. 2005). This symbiosis is especially relevant for P acquisition and could help overcome possible P-induced decreases in legume abundance and biological N fixation (Hainds et al. 1999). Finally, the changes in plant communities occasioned by wildfires, similarly to the changes generated by $\mathrm{CO}_{2}$ enrichment, will probably alter the relative competitive ability between plant and microbes for limiting nutrients, which may indirectly affect the soil microbiota and the outcome of symbiotic associations.

\subsection{Prescribed burning as a management tool for forest ecosystems}

Also relevant to forest functioning is the use of fire as a forest management tool, generally known as controlled or prescribed burning (Guinto et al. 1999b; Mao et al. 2002; Penman and York 2010). Prescribed burning usually involves low intensity, understorey fires (Fig. 3). It is used by forest managers to avoid devastating wildfires by reducing the amount of fuel, to reestablish ecosystem functioning, to control competition and facilitate regeneration, and to manage wildlife habitat (Hendricks and Boring 1999). Because the accumulation of fuels has also been shown to generate stagnation in nutrient 
cycling (Caldwell et al. 2002), prescribed burning may be beneficial for forest functioning. As a forest management tool, periodic fire plays a crucial role in these ecosystems, and may reduce the potential feedbacks of wildfire on climate change. However, burning may act as an additional environmental stressor by affecting the functional interactions between soil biota and plants and favoring some plant or soil microbial species (Guinto et al. 1999a; Bastias et al. 2006a, b). Prescribed burning also generates N volatilization: Johnson et al. (1998) estimated that a fire of moderate-severity would volatilize about $200 \mathrm{~kg} \mathrm{~N} \cdot \mathrm{ha}^{-1}$ from a semi-arid forest ecosystem. Furthermore, it results in increased nutrient availability and in lower nutrient uptake by the plants, thereby increasing $\mathrm{N}$ leaching (Mohamed et al. 2007). Frequent or regular burning may further modify $\mathrm{C}$ and $\mathrm{N}$ cycling patterns by decreasing the quantity of soil organic matter, altering $\mathrm{C}$ allocations in plants, reducing $\mathrm{N}$ mineralization rates and ultimately altering plant succession and evapotranspiration rates (Neary et al. 1999). The frequency of prescribed burning is thus a critical parameter to take into account in forest management, since short fire-return intervals would result in greater $\mathrm{N}$ replacement needs, as would fires of higher severity (Busse et al. 2007). In such cases, additional $\mathrm{N}$ inputs from native legumes would therefore be needed to replace the $\mathrm{N}$ lost through volatilization, although extensive planting would probably be required to ensure the establishment and persistence of legume populations large enough to significantly increase $\mathrm{N}$ availability (Hendricks and Boring 1999).

\section{Understorey legumes as potential indicator species in forest ecosystems}

While there is a relatively large amount of studies focusing on the responses of forest trees to global climate change (Beedlow et al. 2004; Magnani et al. 2007; Bonan 2008), relatively little information has been generated on the understorey vegetation. Legumes are known to be important functional components of the understorey vegetation of forest ecosystems, and are acknowledged to play a crucial role in biological $\mathrm{N}$ fixation. Because $\mathrm{N}$ is often a limiting factor to plant growth and a major constraint on $\mathrm{C}$ storage in ecosystems, $\mathrm{N}_{2}$-fixing plants are a key element in the $\mathrm{N}$ biogeochemical cycle and could mitigate the potential C:N imbalance caused by elevated $\mathrm{CO}_{2}$ through $\mathrm{N}$ inputs into the soil system (Serraj et al. 1998; Forrester et al. 2005). This may be especially true for understorey legumes growing on nutrient-depleted soils, such as the ancient Australian forests soils where even small N inputs by biological N fixation may be significant (Guinto et al. 2000). Forest management practices thus increasingly consider understorey legumes as important to reestablish an adequate balance between inputs and outputs of $\mathrm{N}$ (Adams et al. 2010).

Understorey legumes will have to adapt to the new environmental conditions created by environmental disturbances. Sprent (1995) indicated that Australian acacias may have evolved due to variations in moisture regimes and hence that accelerated land degradation and desertification may continue to exert selection pressure and lead to more speciation. These pressures are likely to act on legume-associated bacteria as well. Rhizobium for instance possesses the ability to survive under stressed environments (Thorne and Williams 1997; Räsänen et al. 2004; Sarr and Lesueur 2007). However, because of the high diversity of nodule-forming bacteria associated with understorey legumes and to their broad distribution (Hoque et al. 2011), different species of symbionts may respond differently to global climate change or fire, which makes the impact of environmental changes on $\mathrm{N}$-fixing microbes difficult to assess. Since legumes and their associated microbes are direct actors in nutrient cycling, they may respond more rapidly to changes in nutrient fluxes, especially because plant-microbes interactions are particularly sensitive to changes in plant physiology and belowground allocation (van der Heijden et al. 2003; Duponnois et al. 2005; Adams et al. 2010).

Acacia is a particularly important genus, with 955 species recorded in Australia. Acacia species possess the capacity to 
accumulate relatively large quantities of cyclitols as a mechanism to cope with drought conditions (Adams et al. 2010), and may therefore be able to play a major role in land rehabilitation and $\mathrm{C}$ sequestration strategies. There is a great diversity in both host and microbial symbionts (formed by both rhizobia and mycorrhizal fungi) in Acacia symbioses. If biodiversity helps maintaining ecosystem functioning in complex environments and may buffer natural ecosystems against ecological impacts of nutrient pollution (Cardinale 2011), it may also help mitigating the negative effects of global climate change. Understorey legumes are important functional species, and even when they cannot reasonably be expected to reestablish nutrient balance in forest soils, they may be used as indicator species to monitor nutrient fluxes and the response of forest ecosystems to changing environmental conditions. Acacia species are sensitive to global climate change and fire management, play a direct role in nutrient cycling and are likely to respond rapidly to any environmental change in nutrient fluxes, and as such represent an interface between forest soils, soil microbes and major trees of the ecosystem. Their ability to fix $\mathrm{N}$ enables an adjustment of $\mathrm{N}$ availability close to the availability of other resources and thereby strongly relies on the fragile equilibrium of biogeochemical cycles (Vitousek and Field 1999). Understorey legumes are functional keystone species in forest ecosystems, and because they are sensitive to environmental changes, they may be good ecological indicators to monitor the response of these forests to enriched $\mathrm{CO}_{2}$ conditions or to wildfires. Moreover, as shown previously, fungi may be favored over bacteria by warming and increasing $\mathrm{N}$ limitations. Since acacias are known to form symbiotic associations with both bacteria and mycorrhizal fungi, they would constitute the perfect model to study the influence of environmental disturbances on the relative abundance of bacterial and fungal communities present in its rhizosphere. Plants may rely more strongly on their symbionts when subjected to stress and the outcome of the symbiosis is likely to change under harsher conditions. It is therefore necessary to study how environmental factors influence the effectiveness of the interaction (Sarr and Lesueur 2007). Finally, getting a better understanding about how environmental stressors affect biological $\mathrm{N}$ fixation is an essential requirement to accurately model ecosystem $\mathrm{N}$ budgets and ultimately for forest ecology and productivity and for ecosystem C storage (DeLuca et al. 2011).

Acknowledgements We acknowledge the funding support from the Australian Research Council (DP0664154, DP0667184, LX0881973, DP1092470).

\section{References}

Abera G, Wolde-meskel E, Bakken LR (2011) Carbon and nitrogen mineralization dynamics in different soils of the tropics amended with legume residues and contrasting soil moisture contents. Biol Fertil Soils (in press)

Adams MA, Simon J, Pfautsch S (2010) Woody legumes: a (re)view from the South. Tree Physiol 30:1072-1082

Allen CD, Macalady AK, Chenchouni H, Bachelet D, McDowell N, Vennetier M, Kitzberger T, Rigling A, Breshears DD, Hogg EHT, Gonzales P, Fensham R, Zhang Z, Castro J, Demidova N, Lim JH, Allard G, Running SW, Semerci A, Cobb N (2010) A global overview of drought and heat-induced tree mortality reveals emerging climate change risks for forests. For Ecol Manage 259:660-684

Atkin OK, Schortemeyer M, McFarlane N, Evans JR (1999) The response of fast- and slow-growing Acacia species to elevated atmospheric CO2: an analysis of the underlying components of relative growth rate. Oecologia 120:544-554

Bastias BA, Huang ZQ, Blumfield T, Xu ZH, Cairney JWG (2006a) Influence of repeated prescribed burning on the soil fungal 
community in an eastern Australian wet sclerophyll forest. Soil Biol Biochem 38:3492-3501

Bastias BA, Xu Z, Cairney JWG (2006b) Influence of long-term repeated prescribed burning on mycelial communities of ectomycorrhizal fungi. New Phytol 172:149-158

Beedlow PA, Tingey DT, Phillips DL, Hogsett WE, Olszyk DM (2004) Rising atmospheric $\mathrm{CO}_{2}$ and carbon sequestration in forests. Front Ecol Environ 2:315-322

Blankinship JC, Niklaus PA, Hungate BA (2011) A meta-analysis of responses of soil biota to global change. Oecologia 165:553-565

Bonan GB (2008) Forests and climate change: forcings, feedbacks, and the climate benefits of forests. Science 320:1444-1449

Busse MD, Jurgensen MF, Page-Dumroese DS, Powers RF (2007) Contribution of actinorhizal shrubs to site fertility in a Northern California mixed pine forest. For Ecol Manage 244:68-75

Caldwell TG, Johnson DW, Miller WW, Qualls RG (2002) Forest floor carbon and nitrogen losses due to prescription fire. Soil Sci Soc Am J 66:262-267

Chen CR, Xu ZH (2010) Forest ecosystem responses to environmental changes: the key regulatory role of biogeochemical cycling. J Soils Sediments 10:210-214

Coetsee C, Bond WJ, February EC (2010) Frequent fire affects soil nitrogen and carbon in an African savanna by changing woody cover. Oecologia 162:1027-1034

Dawson TP, Jackson ST, House JI, Prentice IC, Mace GM (2011) Beyond predictions: biodiversity conservation in a changing climate. Science 332:53-58

DeLuca TH, Aplet GH (2008) Charcoal and carbon storage in forest soils of the Rocky Mountain West. Front Ecol Environ 6:1-7

DeLuca TH, Zackrisson O, Gundale MJ, Nilsson MC (2011) Ecosystem feedbacks and nitrogen fixation in boreal forests. Science 320:1181

Diédhiou AG, Guèye O, Diabaté M, Prin Y, Duponnois R, Dreyfus B, Bâ AM (2005) Contrasting responses to ectomycorrhizal inoculation in seedlings of six tropical African tree species. Mycorrhiza 16:11-17

Drake JE, Gallet-Budynek A, Hofmockel KS, Bernhardt ES, Billings SA, Jackson RB, Johnsen KS, Lichter J, McCarthy HR, McCormack ML, Moore DJP, Oren R, Palmroth S, Phillips RP, Pippen JS, Pritchard SG, Treseder KK, Schlesinger WH, DeLucia EH, Finzi AC (2011) Increases in the flux of carbon belowground stimulate nitrogen uptake and sustain the long-term enhancement of forest productivity under elevated $\mathrm{CO}_{2}$. Ecol Lett 14:349-357

Drigo B, Kowalchuk GA, van Veen JA (2008) Climate change goes underground: effects of elevated atmospheric $\mathrm{CO}_{2}$ on microbial community structure and activities in the rhizosphere. Biol Fertil Soils 44:667-679

Duponnois R, Colombet A, Hien V, Thioulouse J (2005) The mycorrhizal fungus Glomus intraradices and rock phosphate amendment influence plant growth and microbial activity in the rhizosphere of Acacia holosericea. Soil Biol Biochem $37: 1460-1468$

Essendoubi M, Brhada F, Eljamali JE, Filali-Maltouf A, Bonnassie S,Georgeault S, Blanco C, Jebbar M (2007) Osmoadaptative responses in the rhizobia nodulating Acacia isolated from south-eastern Moroccan Sahara. Environ Microbiol 9:603-611

Finzi AC, Austin AT, Cleland EE, Frey SD, Houlton BZ, Wallenstein MD (2011) Responses and feedbacks of coupled biogeochemical cycles to climate change: examples from terrestrial ecosystems. Front Ecol Environ 9(1):61-67 
Finzi A, Norby RJ, Calfapietra C, Gallet-Budynek A, Gielen B, Holmes WE, Hoosbeek MR, Iversen CM, Jackson RB, Kubiske ME, Ledford J, Liberloo M, Oren R, Polle A, Pritchard S, Zak DR, Schlesinger WH, Ceulemans R (2007) Increases in nitrogen uptake rather than nitrogen-use efficiency support higher rates of temperate forest productivity under elevated $\mathrm{CO}_{2}$. Proc Natl Acad Sci USA 104(35):14014-14019

Forrester DI, Bauhus J, Cowie AL (2005) Nutrient cycling in a mixed-species plantation of Eucalyptus globulus and Acacia mearnsii. Can J For Res 35:2942-2950

Gebrekirstos A, van Noordwijk M, Neufeldt H, Mitlöhner R (2011) Relationships of stable carbon isotopes, plant water potential and growth: an approach to asses water use efficiency and growth strategies of dry land agroforestry species. Trees 25:95-102

Gruber N, Galloway JN (2008) An Earth-system perspective of the global nitrogen cycle. Nature 451:293-296

Guinto DF, House APN, Xu ZH, Saffigna PG (1999a) Impacts of repeated fuel reduction burning on tree growth, mortality and recruitment in mixed species eucalypt forests of southeast Queensland, Australia. For Ecol Manage 115:13-27

Guinto DF, Saffigna PG, Xu ZH, House APN, Perera MCS (1999b) Soil nitrogen mineralization and organic matter composition revealed by ${ }^{13} \mathrm{C}$ NMR spectroscopy under repeated prescribed burning in eucalypt forests of south-east Queensland. Aust J Soil Res 37:123-135

Guinto DF, Xu ZH, House APN, Saffigna PG (2000) Assessment of $\mathrm{N}_{2}$ fixation by understorey acacias in recurrently burnt eucalypt forests of subtropical Australia using ${ }^{15} \mathrm{~N}$ isotope dilution techniques. Can J For Res 30:112-121

Hainds MJ, Mitchell RJ, Palik BJ, Boring LR, Gjerstad DH (1999) Distribution of native legumes (Leguminoseae) in frequently burned longleaf pine (Pinaceae)-wiregrass (Poaceae) ecosystems. Am J Bot 86:1606-1614

Hart SC, DeLuca TH, Newman GS, MacKenzie MD, Boyle SI (2005) Post-fire vegetative dynamics as drivers of microbial community structure and function in forest soils. For Ecol Manage 220:166-184

Heimann M, Reichstein M (2008) Terrestrial ecosystem carbon dynamics and climate feedbacks. Nature 45:289-292

Hendricks JL, Boring LR (1999) $\mathrm{N}_{2}$-fixation by native herbaceous legumes in burned pine ecosystems of the southwestern United States. For Ecol Manage 113:167-177

Hoque MS, Broadhurst LM, Thrall PH (2011) Genetic characterization of root-nodule bacteria associated with Acacia salicina and A. stenophylla (Mimosaceae) across south-eastern Australia. Int J Syst Evol Microbiol 61:299-309

Houlton BZ, Wang YP, Vitousek PM, Field CB (2008) A unifying framework for dinitrogen fixation in the terrestrial biosphere. Nature 454:327-330

Hughes L (2003) Climate change and Australia: Trends, projections and impacts. Austral Ecology 28:423-443

Hungate BA, Stiling PD, Dijkstra P, Johnson DW, Ketterer ME, Hymus GJ, Hinkle CR, Drake BG (2004) $\mathrm{CO}_{2}$ elicits longterm decline in nitrogen fixation. Science 304:1291

IPCC Climate Change (2007) Synthesis Report. Summary for Policymakers. http://www.ipcc.ch

Jablonski LM, Wang X, Curtis PS (2002) Plant reproduction under elevated $\mathrm{CO}_{2}$ conditions: a meta-analysis of reports on 79 crop and wild species. New Phytol 156:9-26

Johnson DW, Susfalk RB, Dahlgren RA, Klopatek JM (1998) Fire is more important than water for nitrogen fluxes in semiarid forests. Environ Sci Pol 1:79-86

Johnson DW, Murphy JF, Susfalk RB, Caldwell TG, Miller WW, Walker RF, Powerset RF (2005) The effects of wildfire, salvage logging, and post-fire N fixation on the nutrient budgets of a Sierran forest. For Ecol Manage 220:155-165 
Langley JA, Megonigal JP (2010) Ecosystem response to elevated $\mathrm{CO}_{2}$ levels limited by nitrogen-induced plant species shift. Nature 466:96-99

Laurance WF, Dell B, Turton SM, Lawes MJ, Hutley LB, McCallum H, Dale P, Bird M, Hardy G, Prideaux G, Gawne B, McMahon CR, Yu R, Hero JM, Schwarzkopf L, Krockenberger A, Douglas M, Silvester E, Mahony M, Vella K, Saikia U, Wahren CH, Xu ZH, Smith B, Cocklin C (2011) The ten Australian ecosystems most vulnerable to tipping points. Biol Conserv 144:1472-1480

Liu JX, Zhou GY, Xu ZH, Duan HL, Li YL, Zhang DQ (2011a) Photosynthesis acclimation, leaf nitrogen concentration, and growth of four tree species over 3 years in response to elevated carbon dioxide and nitrogen treatment in subtropical China. J Soils Sediments 11:1155-1164

Liu JX, Xu ZH, Zhang DQ, Zhou GY, Deng Q, Duan HL, Zhao L, Wang CL (2011b) Effects of carbon dioxide enrichment and nitrogen addition on inorganic carbon leaching in subtropical model forest ecosystems. Ecosystem 16:683-697

Liu JX, Zhou GY, Zhang DQ, Xu ZH, Duan HL, Deng Q, Zhao L (2010) Carbon dynamics in subtropical forest soil: effects of atmospheric carbon dioxide enrichment and nitrogen addition. J Soils Sediments 10:730-738

Lüscher A, Hartwig UA, Suter D, Nösberger J (2000) Direct evidence that symbiotic $\mathrm{N}_{2}$ fixation in fertile grassland is an important trait for a strong response of plants to elevated atmospheric $\mathrm{CO}_{2}$. Glob Change Biol 6:655-662

Magnani F, Mencuccini M, Borghetti M, Berbigier P, Berninger F, Delzon S, Grelle A, Hari P, Jarvis PG, Kolari P, Kowalski AS, Lankreijer H, Law BE, Lindroth A, Loustau D, Manca G, Moncrieff JB, Rayment M, Tedeschi V, Valentini R, Grace G (2007) The human footprint in the carbon cycle of temperate and boreal forests. Nature 447:848-850

Mao XA, Xu ZH, Luo RS, Mathers NJ, Zhang YH, Saffigna PG (2002) Nitrate in soil humic acids revealed by nitrogen-14 nuclear magnetic resonance spectroscopy. Aust J Soil Res 40:717-726

Mohamed A, Härdtle W, Jirjahn B, Niemeyer T, von Oheimb G (2007) Effects of prescribed burning on plant available nutrients in dry heathland ecosystems. Plant Ecol 189:279-289

National Forest Inventory (2007) Australia's Forests at a Glance. National Forest Inventory, Bureau of Rural Sciences, Canberra

Neary DG, Klopatek CC, DeBano LF, Folliott PF (1999) Fire effects on belowground sustainability: a review and synthesis. For Ecol Manage 122:51-71

Nelson JA, Morgan JA, LeCain DR, Mosier AR, Milchunas DG, Parton BA (2004) Elevated $\mathrm{CO}_{2}$ increases soil moisture and enhances plant water relations in a long-term field study in semi-arid shortgrass steppe of Colorado. Plant Soil 259:169-179

Newland JA, DeLuca TH (2000) Influence of fire on native nitrogen-fixing plants and soil nitrogen status in ponderosa pine - Douglas-fir forests in western Montana. Can J For Res 30:274-282

Norby RJ, Ledford J, Reilly CD, Miller NE, O`Neill EG (2004) Fine-root production dominates response of a deciduous forest to atmospheric $\mathrm{CO}_{2}$ enrichment. Proc Natl Acad Sci USA 101(26): 9689-9693

Oren R, Ellsworth DS, Johnsen KH, Phillips N, Ewers BE, Maier C, Schäfer KVR, McCarthy H, Hendrey G, McNulty SG, Katul GG (2001) Soil fertility limits carbon sequestration by forest ecosystems in a $\mathrm{CO}_{2}$-enriched atmosphere. Nature 411:469-472

Owens PN, Xu ZH (2011) Recent advances and future directions in soils and sediments research. J Soils Sediments 11:875888 
Penman TD, York A (2010) Climate and recent fire history affect fuel loads in Eucalyptus forests: Implications for fire management in a changing climate. For Ecol Manage 260:1791-1797

Peñuelas J, Rutishauser T, Filella I (2009) Phenology feedbacks on climate change. Science 324:887-888

Pritchard SG (2011) Soil organisms and global climate change. Plant Pathol 60:82-99

Räsänen LA, Saijets S, Jokinen K, Lindström K (2004) Evaluation of the roles of two compatible solutes, glycine betaine and trehalose, for the Acacia senegal-Sinorhizobium symbiosis exposed to drought stress. Plant Soil 260:237-251

Reich PB, Tilman D, Craine J, Ellsworth D, Tjoelker MG, Knops J, Wedin D, Naeem S, Bahauddin D, Goth J, Bengtson W, Lee TD (2001) Do species and functional groups differ in acquisition and use of $\mathrm{C}, \mathrm{N}$ and water under varying atmospheric $\mathrm{CO}_{2}$ and $\mathrm{N}$ availability regimes? A field test with 16 grassland species. New Phytol 150:435-448

Reich PB, Hobbie SE, Lee T, Ellsworth DS, West JB, Tilman D, Knops JMH, Naeem S, Trost J (2006) Nitrogen limitation constrains sustainability of ecosystem response to CO2. Nature 440:922-925

Rogers A, Gibon Y, Stitt M, Morgan PB, Bernacchi CJ, Ort DR, Long SP (2006) Increased C availability at elevated carbon dioxide concentration improves $\mathrm{N}$ assimilation in a legume. Plant Cell Environ 29:1651-1658

Rogers A, Ainsworth EA, Leakey ADB (2009) Will elevated carbon dioxide concentration amplify the benefits of nitrogen fixation in legumes? Plant Physiol 151:1009-1016

Sarr A, Lesueur D (2007) Influence of soil fertility on the rhizobial competitiveness for nodulation of Acacia senegal and Acacia nilotica provenances in nursery and field conditions. World J Microbiol Biotechnol 23:705-711

Schimel DS (1995) Terrestrial ecosystems and the carbon cycle. Glob Change Biol 1:77-91

Schortemeyer M, Atkin OK, McFarlane N, Evans JR (2002) $\mathrm{N}_{2}$ fixation by Acacia species increases under elevated atmospheric $\mathrm{CO}_{2}$. Plant Cell Environ 25:567-579

Serraj R, Sinclair TR, Allen LH (1998) Soybean nodulation and $\mathrm{N}_{2}$ fixation response to drought under carbon dioxide enrichment. Plant Cell Environ 21:491-500

Sitch S, Huntingford C, Gedney N, Levy PE, Lomas M, Piao SL, Betts R, Ciais P, Cox P, Friedlingstein P, Jones CD, Prentice IC, Woodward FI (2008) Evaluation of the terrestrial carbon cycle, future plant geography and climate-carbon cycle feedbacks using five Dynamic Global Vegetation Models (DGVMs). Glob Change Biol 14:2015-2039

Soussana JF, Hartwig UA (1996) The effects of elevated $\mathrm{CO}_{2}$ on symbiotic $\mathrm{N}_{2}$ fixation: a link between the carbon and nitrogen cycles in grassland ecosystems. Plant Soil 187:321-332

Sprent JI (1995) Legume trees and shrubs in the Tropics: $\mathrm{N}_{2}$ fixation in perspective. Soil Biol Biochem 27:401-407

Sun F, Kuang Y, Wen D, Xu Z, Li J, Zuo W, Hou E (2010) Long-term tree growth rate, water use efficiency, and tree ring nitrogen isotope composition of Pinus massoniana L. in response to global climate change and local nitrogen deposition in Southern China. J Soils Sediments 10:1453-1465

Thorne SH, Williams HD (1997) Adaptation to nutrient starvation in Rhizobium leguminosarum bv. phaseoli: Analysis of survival, stress sesistance, and changes in macromolecular synthesis during entry to and exit from stationary phase. J Bact 179:6894-6901

Thrall PH, Bever JD, Slattery JF (2008) Rhizobial mediation of Acacia adaptation to soil salinity: evidence of underlying trade-offs and tests of expected patterns. J Ecol 96:746-755

Thrall PH, Broadhurst LM, Hoque MS, Bagnall DJ (2009) Diversity and salt tolerance of native Acacia rhizobia isolated from saline and non-saline soils. Austral Ecol 34:950-963 
Thrall PH, Laine AL, Broadhurst LM, Bagnall DJ, Brockwell, J (2011) Symbiotic effectiveness of rhizobial mutualists varies in interactions with native Australian legume genera. PloS ONE 6(8): e23545

Tobita H, Uemura A, Kitao M, Kitaoka S, Utsugi H (2010) Interactive effects of elevated $\mathrm{CO}_{2}$, phosphorus deficiency, and soil drought on nodulation and nitrogenase activity in Alnus hirsuta and Alnus maximowiczii. Symbiosis 50:59-69

Treseder KK, Mack MC, Cross A (2004) Relationships among fires, fungi, and soil dynamics in Alaskan boreal forests. Ecol Appl 14:1826-1838

van der Heijden MGA,Wiemken A, Sanders IR (2003) Different arbuscular mycorrhizal fungi alter coexistence and resource distribution between co-occuring plant. New Phytol 157:569-578

van Groenigen KJ, Six J, Hungate BA, de Graaff MA, van Breemen N, van Kessel C (2006) Element interactions limit soil carbon storage. Proc Natl Acad Sci USA 103(17):6571-6574

Vitousek PM, Cassman K, Cleveland C, Crews T, Field CB, Grimm NB, Howarth RW, Marino R, Martinelli L, Rastetter EB, Sprent JI (2002) Towards an ecological understanding of biological nitrogen fixation. Biogeochem 57:1-45

Vitousek PM, Field CB (1999) Ecosystem constraints to symbiotic nitrogen fixers: a simple model and its implications. Biogeochem 46:179-202

West JB, HilleRisLambers J, Lee TD, Hobbie SE, Reich PB (2005) Legume species identity and soil nitrogen supply determine symbiotic nitrogen-fixation responses to elevated atmospheric $\left[\mathrm{CO}_{2}\right]$. New Phytol 167:523-530

$\mathrm{Xu} \mathrm{ZH}$, Chen CR (2006) Fingerprinting global climate change and forest management within rhizosphere carbon and nutrient cycling processes. Environ Sci Pollut Res 13:293-298

Xu ZH, Chen CR, He JZ, Liu JX (2009) Trends and challenges in soil research 2009: linking global climate change to local long-term forest productivity. J Soils Sediments 9:83-88

Zahran HH (2001) Rhizobia from wild legumes: diversity, taxonomy, ecology, nitrogen fixation and biotechnology. J Biotech 91:143-153

Zanetti S, Hartwig UA, Lüscher A, Hebeisen T, Frehner M, Fischer BU, Hendrey GR, Blum H, Nosberger J (1996) Stimulation of symbiotic $\mathrm{N}_{2}$ fixation in Trifolium repens L. under elevated atmospheric $\mathrm{pCO}_{2}$ in a grassland ecosystem. Plant Physiol 112:575-583 


\section{Figure Captions}

Fig. 1 Conceptual model describing the responses of understorey legumes and their associated microbes to global climate change. The increase in photosynthesis is expected to 1) lead to larger $\mathrm{C}$ inputs to the roots, enhancing microbial activity and consequently decomposition of litter and organic matter; and 2) increase the $\mathrm{C}: \mathrm{N}$ ratio of the plants, hence enhancing $\mathrm{N}$ uptake and biological $\mathrm{N}$ fixation by the plants. The larger litter C:N ratio may in turn decrease litter decomposition rates and subsequent nutrient releases. The $\mathrm{C}$ sequestration by forest soils is directly linked with the soil organic matter decomposition rates.

Fig. 2 Conceptual model describing the responses of understorey legumes and their associated microbes to fire. Fire is expected to 1) generate a $\mathrm{C}$ and $\mathrm{N}$ loss by volatilization; 2) lead to changes in the species composition of legumes and associated symbionts, either directly or by altering soil nutrient availability; and 3) decreasing soil available $\mathrm{N}$ by $\mathrm{N}$ mineralization, which could enhance $\mathrm{N}_{2}$ fixation and increase $\mathrm{N}$ inputs to the soil.

Fig. 3 A prescribed burning fire conducted on 11 August 2011 in a sub-urban forest of Brisbane, Australia. 